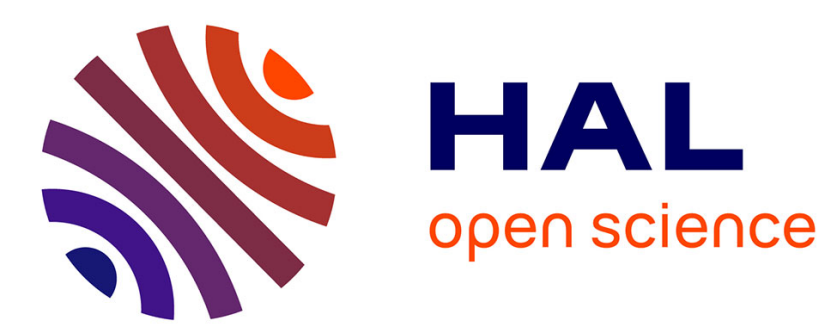

\title{
New social conflicts in the Guangdong province: historical and sociological perspectives
}

\author{
Jean Ruffier
}

\section{To cite this version:}

Jean Ruffier. New social conflicts in the Guangdong province: historical and sociological perspectives. RICHET, DELTEIL, DIEUAIDE eds. Strategies of Multinational Corporations and Social Regulations: European and Asian Perspectives, Springer, 2014, 10.1007/978-3-642-41369-8_12 . hal01266592

\section{HAL Id: hal-01266592 \\ https://hal.science/hal-01266592}

Submitted on 4 Feb 2016

HAL is a multi-disciplinary open access archive for the deposit and dissemination of scientific research documents, whether they are published or not. The documents may come from teaching and research institutions in France or abroad, or from public or private research centers.
L'archive ouverte pluridisciplinaire HAL, est destinée au dépôt et à la diffusion de documents scientifiques de niveau recherche, publiés ou non, émanant des établissements d'enseignement et de recherche français ou étrangers, des laboratoires publics ou privés. 


\title{
DRAFT PAPER
}

\section{New social conflicts in the Guangdong province: historical and sociological perspectives}

\author{
2011 November \\ Jean RUFFIER \\ Chercheur CNRS
}

Centre franco-chinois de sociologie de recherche sur les organisations, Université Sun Yatsen à Canton, 中法组织研究中心, 中山大学, 社会学系

Centre de Recherches Magellan

IAE, Université Jean-Moulin Lyon3

jean.ruffier@univ-lyon3.fr

\begin{abstract}
Over the past year, we saw a proliferation of disputes. Newspapers have even reported several conflicts in the Taiwanese and Japanese companies, which have resulted in very substantial increases in wages. The movement is so strong that more and more observers are discussing the possibility of a general strike in southern China.

Without being able to predict something unpredictable, we believe that conditions are gathered for a workers' spring in South China, with an explosive or creeping movement, which has already begun. We do think that it is just a beginning.

The Sino-French Centre of research on organizations, and Sociological Department of Sun Yatsen University in Canton, conducted observations on field and discussions with companies, unions, activists and authorities that we would like to report in this paper and which offer us a better picture of what is going to happen.

The chapter begins with by a discussion on the motivations of strikes. Then it will focus on the different actors interacting in social conflicts, trying to describe shortly their aims and strategies. All together everything seems set to prepare more strikes to come

The era of low wages and obedient Chinese workers is about to end If Guangdong, China biggest southern province - became the workshop of the world, this is due to several reasons but the main one is the existence of a labour force, obedient, and accepting without protest
\end{abstract}


low wages and poor working conditions. Over the past twenty years, growth has been uninterrupted and wages have barely changed ${ }^{1}$. Chinese governmental statistics show that these wages would have rather decreased in proportion to the gross industrial product.

\section{Methodology and data}

In order to collect data for that paper, we used mostly field work of SUN Yatsen University SinoFrench Research Centre on Organisations. That Centre exists from 2000 and has always been leaded by one French and one Chinese Directors. He mostly studies Delta Pearl River Factories, giving advises to Chinese and Foreign managers and to local industrial policy makers. That gives us access to workers, bosses and executive all over China. The study on labour conflicts was decided by the two directors and was helped by SUN Yatsen University Labour Studies Centre.

We too used labour statistics even if most are faked, they give us trends. We red newspapers even if they can report only on a conflict only if it is required by authorities. Because they are looking for foreign advises, we had the opportunity to discuss with Chinese unions. We participate a meeting between Shanghai union and Lyon unions helping both parts to understand the other part.

\section{Why do workers strike?}

is an American economist known for a theory of collective action, published in 1965 According to him, strike is primarily the result of a calculation: the workers think about what they might lose (unpaid hours, bosses or government retaliation) and what is at stake (wage increase $)^{2}$. The seeking of these interests matches the mood of numerous Chinese workers. According to Olson, there is no action without coercion, because you earn more money if you let others strike for an increase but not to strike yourself to avoid losing your pay. The constraint requires a minimum of organization, and this explains why the strikes were so difficult to arrange in China until now: we know how the Chinese government violently crushed the very beginning of any rival organization of the Party.

\footnotetext{
${ }^{1}$ To understand better Chinese industrial development, see: R. Arvanitis et W. Zhao, "Five Cases Studies of Private and Collective enterprises in Guangdong ", dans J.-F. Huchet et W. Wang (dir.), Chinese Firms in the Era of Globalisation, Beijing, China Development Publishing House, 2008 ; W.A. Byrd (dir.), Chinese Industrial Firms under Reform, Oxford, Oxford University Press, 1992; Y. Cao, Y. Qian et B.R. Weingast, "The Sale Goes on. Transforming Small enterprises in China», Transition, février 1998, p. 5-7; Y. Huang, Capitalism with Chinese Characteristics, Cambridge, Cambridge University Press, 2008; F. Navarro, "L'avantage concurrentiel chinois entre pratiques déloyales et avantages comparatifs ", Perspectives chinoises, Hongkong, no 97, 2006, p. 13-29 ; H. Qin, Les leçons à tirer du miracle chinois, Lingdaozhe, Pékin; H. Qiu (éditeur), "Innovation régionale et développement d'entreprise», Pékin, Éditions des sciences économiques/UNESCO), 2007 ; J. Ruffier, Faut-il avoir peur des usines chinoises ? Compétitivité et pérennité de l'atelier du monde, Paris, L'Harmattan, 2006, p. 186.

2 Mancur OLSON (1971), The Logic of Collective Action: Public Goods and the Theory of Groups, Harvard University Press, 1st ed. 1965, 2nd ed. 1971
} 
In the first thirty years of the communist regime in China, being a worker meant to have a certain level of education and the privilege of working for the State. The reforms have substantially reduced the percentage of workers in State enterprises to the profit of private enterprises. These one have massively hired uneducated and poor young people coming from the countryside.

\section{A new generation of workers}

Thirty years after the industrial take-off, we face now the second generation of workers from rural areas. This second generation has a better education than the first one. It gets the experience of the first generation, and above all, it has known nothing but economic growth. The first generation of workers from rural areas had experienced civil wars and periods of starvation. The current generation knows what misery is, but it has rarely been confronted with starvation, and almost never to repression. This is a generation that believes in its future.

These workers have left villages that young people are fleeing or where there is unemployment. The average income of Chinese farmers is currently around $100 €$ per year, the one of the factory workers is ten times higher. The workers of rural origin have thus experienced a genuine social advancement.

Twenty years observation of Chinese factories gave us the opportunity to observe changes in the attitudes of these workers. It is impossible to describe the variety of views of the Chinese workers, but we can try out to sort some usual workers speeches when they refer to observed situations. The medias place great emphasis on working conditions that are often no better than any other third world countries These working conditions are indeed resented, but they are also seen as inavoidable. However, the work intensity increases. Twenty years ago, most plants that I observed were not enviable for their working conditions, but the work rhythm was not too hard.

There were many reasons for this: Firstly wages were so low that it did not require a significant amount of work. Perhaps the main reason is that it is not easy to make workers work hard. Taylor has highlighted the need to mobilize a lot of intellectual work to achieve an increase of work productivity, and Chinese factories face a lack of organizers ${ }^{3}$. So it is very gradually that work rates have increased. Working hours were lengthened due to a growing demand of work production. Employees and managers have also faced growing work intensity Chinese employees did not mind working longer: the low intensity of their work and the improvement of their life quality justified it. In the last years of the twentieth century, the workers demanded more hours because they wanted to increase their income, work more to earn more was very fashionable at that time. This workalcoholism nourished a

\footnotetext{
${ }^{3}$ Frederick Winslow TAYLOR (1911), Principles of Scientific Management. New York and London, Harper \& brothers.
} 
form of triumphant nationalism. During the years 2004-2006, we heard Chinese friends who mocked the supposed laziness of the West, which they said were more concerned with multiplying days off than developing their national economies. They told us that the Chinese economy would become more powerful because the Chinese themselves were not afraid to work and even willing to work hard for limited wages. We are no more listening this kind of speeches nowadays The pace of work increased. It must also be said that you can work intensely for several years but not indefinitely. If you work too much, you eventually get exhausted, even if you are Chinese.

\section{Work less and earn more}

Today we hear many Chinese saying they want to work less Workers are often more invested in their work in relation to the gains which result of it. They often make disillusioned observations: "We worked increasingly hard for years, and look who benefited of it - not we! ". If these workers earn more than their parents, they are also in a world more complicated. Chinese workers' wages have not kept pace with China's economic growth. They remain third world countries wages in a region where GDP per capita is close to the one of eastern European countries. Making a living as a worker becomes a puzzle. Housing prices soared. While the majority of urban dwellers own their home, the workers realize they will not succeed. Getting married involves finding accommodation outside cheap dormitories. Raising a child in the city is often out of reach for a worker due to his financial income. Most of the time, they choose to let the grandparents raise their child in the countryside, or to postpone indefinitely the birth. And recently, food prices are also rising.

A few years ago, workers took their fate with fatalism, because they saw no way of improvement. But today they heard of wages rise in other plants as a result of strikes, and they feel they are underpaid. They have not experienced repression, are accustomed to changing business easily and they do not fear unemployment; therefore, they are not afraid to strike. It must be said that unlike their parents, these workers are usually issued from the one child policy, so they were used to get all the attention of their parents: they hardly bear frustration. If they do not strike very often, it is because most of them don't know how to organize it.

\section{Employers distraught over tensions}

Facing their changing attitudes, private employers often seem clueless. Chinese private employers were accustomed to docile workers, but not loyal. They adapted to a high turnover especially since they had no trouble recruiting. Turnover appeared to be the best way to manage tensions When recruiting new employees became more difficult, they only needed to slightly increase wages or improve housing conditions. In interviews with employers, unqualified workers appeared only very rarely as a major concern. Now, those same bosses are faced with people who openly discuss wages and this is new for them. They appeal to 
authority, the Confucian virtues of obedience and show toughness in dealing with the workers. These employers have little opportunity to discuss in depth with colleagues Chinese employers are not allowed to organize themselves in association. No surprise that they are coping badly with social troubles in their factories.

The communist government has sufficient knowledge of the thinking of Karl Marx to understand that if China becomes a capitalist country, capitalists should one day take the power. The authorities do everything they can to delay the time for this Marxist prophesies to become true. As a result, the Chinese bosses have little places to debate together on common strategies, and no real way to express themselves collectively. There are official employers' organizations, but they are run entirely by Communist Party. The only ones who can speak for the employers are employers' organizations in Hong Kong or foreign trade chambers. Western business leaders are also taken aback by this attitude change of the workers. Unlike most of their Chinese counterparts, they usually set up a minimum of Human Relation management, and they try to have good relations with their employees. As a result, they know better and the staff generally knows who is likely to trigger unrest.

But they felt they were able to maintain social peace in anticipating the claims. Their workers usually look satisfied with the situation and hardly do not even complained of wages or working conditions. Yet here, in the last few months, they realize that increases in wages or benefits granted, was not enough to calm the discussions in the workshops. They feel like giving gifts to people who in return tell them that they should give them more. This situation is new for them in China.

Of course, foreign bosses expected to have to raise wages. They were rather surprised not to have to do it earlier. In terms of wages, Western employers visions differ, depending on whether their activity is directed towards the Chinese market or not. If they are in China to take advantage of low cost and industrial facilities, they are reluctant to increase wages and they tend to take the minimum wage as base salary. If they target the Chinese market, the fact that a larger part of their national wealth is redistributed hinted that growth of the Chinese market which should make their business profitable and that they often wait for years. Those who target the Chinese market have generally more long-term policies and favour more their workforce. Moreover, it is in these foreign companies facing the Chinese market that most of Chinese employees want to work.

Facing workers who are not afraid of conflict, authorities are much more divided on the issue of social risk Chinese political power is not a model of democracy. The methods of nomination are by appointment from top to the bottom.

\section{A power less monolithic than we think}


The power is much less monolithic than were those of Eastern Europe when it was socialist. The visions, strategies and situations of the central government are very different from those of municipal authorities or provincial powers.

The personality of the party cadres is also important Joining the Party is an opportunity not offered to everyone. It often requires a lot of effort. But the motivations of the candidates strongly varied: some wish to defend the ideological and legal options, while others seek personal enrichment. The authorities in China are traversed by heated debates on policy implementation. This particularly appears in the management of labour disputes.

The central government intervenes rarely in these conflicts. If it does, it's always a disavowal of local authorities and often brutal. His main concern is to protect its power, and that's for this purpose it will consider whether to intervene. The government has always opposed violently to the creation of autonomous militant organizations.

\section{China is a "cryptocracy"}

Chinese government does not deny the growing number of social conflicts. Even if only few conflict statistics are given, not always reliable, for two years, the authorities have noted increasing number of conflicts and announced they expected other major conflicts. A way to say they are ready to cope with social unrest. We know very little about the central government. China remains essentially a "cryptocracy". The main leaders remain in the shadow and give very few information on the internal conflicts among them. Most of the time, we have seen two leaders, one who seemed to embody the opening, while the other opted for continuity, just as two puppets pulled by the strings. China has a form of power with few equivalents elsewhere or in the past. This is not a personal power but an oligarchy or government of a few. It is a small group of leaders, consisting initially of survivors of the long march, which took the power in 1949. This small group formed a small private company that reproduces within the last sixty years and retains the reins of power Foreign observers generally agree to say that a collective takes key decisions.

\section{An oligarchy of exceptional longevity}

This group holds firmly the reins of a Communist Party composed of hundreds of thousands of people. The oligarchy solves the problem of transmitting power from one generation to another. The same people who are responsible for errors in the initial planning, thus the crimes of the Cultural Revolution, are now those who run the so-called policy of "market socialism" or opening. This explains the longevity of the regime.

We can have a better idea of the power of this oligarchy when it is said that $98 \%$ of Chinese billionaires are related to persons who hold or have held ministerial positions. The relative strength of the group over one person is a leader did too visible mistakes; the group of people has already a plan to correct the effects of these mistakes and suggest alternative solutions. 
Chinese leaders are not smarter than the leaders of other countries, but their system is more "forgiving", by correcting errors made by their leaders. And the duration of the group is potentially infinite. The central government does not work for posterity, like a potentate who knows he will die; it does not work to prove its results in sight of the next election, since there are not real elections The government has the ability and interest to project its country in the long term Due to the large opacity of the central government, it is very difficult to predict how they would react to a major social crisis.

Generally, this is the municipal authority that is responsible to intervene in labour disputes. They are the one who manage Chinese's daily life. They manage social rights, which vary considerably from one city to another The minimum wage is generally set by city. The union appears to be a municipal authority. Municipal authorities are the first on the front line in case of complaints. Of course, they are sensitive to the pressure from the central government, but their action is intended to show that they control the situation It happened that municipalities should bear the last wages of employees in case of bankruptcy of the contractor. Like all cities, they wish to accommodate more businesses and get more taxes. This means that in conflicts, they are rather sensitive to the arguments of employers rather than those of workers Thus, cities can send the police, or mobilize the union to end a conflict.

\section{Guangdong, laboratory of social experimentation}

Province got from Central Government the mission and ambition to have an advanced economic development and political openness It is a roadmap already old, but updated recently. In its program, the province has to take the form of a developed country and abandon the attributes of the third world. They want to move towards high technology industries with creation of high value added economic activities. It is also the province that does the most research and development; the province files the most patents and receives most of foreign investment.

Province's number one, the party secretary, regularly takes avant-garde positions. He pushed for social laws that will be more stringent than anywhere else.This should complicate the life of struggling industries whose strategy is based mainly on the exploitation of low-cost labour. Province's number two, the governor of the province, appears more concerned with social harmony. He wants to avoid the tensions that will inevitably arise if a new production model let people aside. This balance between two heads is rather classical. But it may give the impression of a hesitant power, which does not facilitate the task of those who have to manage conflict. The province has taken leading positions in the representation of employees.

Employees currently have no real way of representation because of the violent repression of any organization supposed to compete with the Communist Party. This situation makes it particularly difficult to manage conflict, companies having to guess why there is a conflict without being able to meet representatives of the people involved in the conflict. However, in 2010, the Party Secretary of the province has repeatedly stressed the need to directly elect 
representatives of employees He even proposed a law for that purpose, but decided to delay it because of opposition from employers' organization in Hong Kong. The reluctance of the authorities is especially noticeable when you look closely at union leaders. Union officials in Guangdong are quite divided on the role of unions and the strategy to pursue in a conflict In the Chinese constitution, the union is primarily a propaganda organ of the Party turned to the employees Most of their actions consist in various campaigns for social education. The union does not represent the employees, they defends them in seeking what can improve the workers situation.

\section{Unions seek to reduce social tensions}

Over the past year, unions got a new mission by the central government: to help reduce social tensions. The first consequence is to increase union presence in firms. In fact, the union is present mainly in state enterprises and joint ventures Currently, unions seek to enter the $100 \%$ foreign companies. These one usually disagree with unions' intrusion as they fear more bureaucracy adds to the running of the company, increases of social costs, with limited things done to reduce tensions in the workplace. The union is virtually absent from Chinese private firms. During a strike, the union does not hesitate to take the initiative to fire striking employees, or hire non-strikers. This can disrupt the workshops, while creating resentment against the company. It is not uncommon that the union is sending militias to bit the strikers.

\section{Sometimes, the union stands by the workers' side}

The union is driven by many debates. We personally participated in meetings of Chinese and French trade unionists where the first asked the second advices in understanding employees. We also found that in Guangdong, the internal debate could go further. There is a centrist trend that considers that in any dispute, the union's role is to be located halfway between employers and employees to find as quickly as possible solution to the conflict. There are other Cantonese unionists who feel that they should stand firmly on the side of workers against the bosses This position is easier to hold when the boss is a foreigner. Thus, in Guangdong, we saw a union involved in a factory on strike electing delegates from the workshops, which were responsible for negotiating the exit of the conflict. This conflict resulted in an important and rapid increase in wages.

All conflicts are not wined by workers. Sometimes, especially in the case of Chinese private employers, workers get nothing.

\section{Activists, uncontrolled actors of the social fight}

We cannot conclude this overview of actors of these conflicts without speaking about the activists There are activists working condition beyond the union and fighting for the betterment of workers. Some are related to training or giving advice NGO. They are often students who decide to spend some of their time to help workers. Their action is essentially to 
inform workers on their rights and which institutions may help workers in cases of abuse. These people are courageous in the sense that their NGO may be an embryo of labour organization, thus running a real risk. At the same time, the authorities sometimes recognize the usefulness of their actions, which generally stay within a legal framework. Thus, the union can require an employer to provide training to their employees about their rights.

There are other activists more determined to defend the rights of workers, including by organizing strikes. These activists are more difficult to meet because the authorities hunt them. They are no less active. Thus, we have heard people claiming they entered big companies to strike. Once the strike is over, these activists tend to disappear in the wild. Their action is not very difficult because their speeches are quite close to the views of a majority of workers. Basically, they explain to other workers that they are exploited and that their situation can be improved by struggling. And most importantly, they give the start of the conflict. This was the case of a multinational where militants had managed to persuade many workers to strike. Together, they decided which day and hour the strike should begin In due course, nobody dared to strike. An activist then cut the power in his workshop. The workers alerted their colleagues by SMS in other workshops, and the strike began that way. Later, the strike was in other plants of the same company. It lasted several weeks and ended with large increases in wages but also layoffs and the departure of all militants and some strikers.

\section{We have not reached the peak of the conflicts}

This panorama of actors, determination and fearlessness of the workers on one hand, the employers' confusion and indecision of the authorities on the other hand, all this suggests that these conflicts will multiply. Some activists and intellectuals even imagine they will take the form of a general strike starting from local conflicts spreading. So we strongly suggest the peak of the conflicts is yet to come. Wage could increase more without harms for economic development or enterprise wealth. All these elements make me suppose that wages will rise rapidly in South China.

As we have seen, this will not affect much the presence of foreign firms. Certainly, it will become less attractive to move to China to benefit from low wages, but those who are there already will think twice before moving elsewhere, while a new purchasing power is emerging. The workers' spring in South China is going on... 